University for Business and Technology in Kosovo

UBT Knowledge Center

Oct 28th, 2:30 PM - 4:00 PM

\title{
Genealogical Analysis of Bar's Body Activity in Hemophilia at Two Brothers and a Cousin
}

Naser Kamberi

University for Business and Technology, naser.kamberi@ubt-uni.net

Follow this and additional works at: https://knowledgecenter.ubt-uni.net/conference

Part of the Food Science Commons

\section{Recommended Citation}

Kamberi, Naser, "Genealogical Analysis of Bar's Body Activity in Hemophilia at Two Brothers and a Cousin" (2017). UBT International Conference. 168.

https://knowledgecenter.ubt-uni.net/conference/2017/all-events/168

This Event is brought to you for free and open access by the Publication and Journals at UBT Knowledge Center. It has been accepted for inclusion in UBT International Conference by an authorized administrator of UBT Knowledge Center. For more information, please contact knowledge.center@ubt-uni.net. 


\title{
Genealogical Analvsis of Bar's Bodv Activitv in Hemophilia at Two Brothers and a Cousin
}

\author{
Naser Kamberi ${ }^{1}$ \\ ${ }^{1}$ UBT - Higher Education Institution, Lagjja KALABRIA p.n., Prishtinë, Kosovë \\ 10000 Prishtina, Kosovo \\ naser.kamberi@ubt-uni.net
}

\begin{abstract}
In this study it is included a sample of the Presevo population and villages of 3771 individuals. During family interviews, we encountered cases in women with hemophilia and men with hemophiliacs. Predicting that X-sex chromosome is inactive we did not have the case that females are hemophilic. By doing the genealogical analysis of these families, we will present the thoughts about the role of Bari's body when it comes to hemophilia.

The genealogical method can be used especially in cases of monogenic inheritance. Considering that if the X chromosome is inactive in women then the dose of the chromosome is equal to the male sex. For this reason, likely to get sick of hemophilia would be equal, but in reality this does not stand. So with this study we will give our thoughts about the Bar's body or the gender heterochromatin regarding the dilemma of this case.
\end{abstract}

Keywords: Kromosom X, Barr body, hamophyli, genealogy.

\section{INTERDUCTION}

Bari and Bertram in 1949 observed that X chromosome inactivated at embryo stage at implant time at the end of the first week of pregnancy. This chromosome is accumulated in a cluster in which the genes in it are thought to be inactive and this chromosome is called Bari's body.

With this paper, the effect of "sex inactivated" X chromosome in the cases of individuals with related diseases for this X chromosome is studied. Based on the cases we are going to present; will we clarify that chromosome as the body of Bari has an impact on inheritance or has no influence? We present this phenomenon in the dilemma because only males are sick with hemophilia, while women are not based on data obtained from the four-generation populationgenerated genealogy study in which hemophilic cases appear.

\section{MATERIAL AND METHOD}

For this work as a part of the $\mathrm{PhD}$ thesis, the material was taken from the human population in the Presevo municipality where 3771 individuals are involved, including 1727 individuals from Presevo and 2044 individual villages. During the interview method for haemophilists we have had cases of sick boys and women carrying haemophilia but not diseased. To accumulate the material, we combine the method of interview with the method of coding genealogical digit. Using genealogy coding we have been able to convey inherited diseases like hemophilia and other cases. We have assembled the material gathered in the form of a questionnaire in different families without making any selections of them. And all of the cases have been marked in the tables prepared at the excel computer. 
Also in the drawings we made genealogy in cases where we encountered hemophiliaus disease and then genealogy was worked with the genealogy program prepared by S.Vezi-Tirana specializing in genealogical programming. During interviews we can find cases in other villages where they were married by families with hemophilia. But in all cases investigating we did not encounter sick women. Drawing on all these occasions we will give some thoughts about the activity of the burial of Bari

\section{RESULTS AND DISCUSSIONS}

The material received from the interviews in three settlements we have managed to include 97 families.

By tracking the visibility of the traits across the generations we have come to observe the cases of families with hemophilia. These cases were present in 7 families but we analyzed in detail three of them. Based on the analysis we found that hemophilia was evident in these families.

From this study we can emphasize that women though based on scientific thoughts have a sexual chromosome $\mathrm{X}$ and the other is inactive inactive, are not hemophilic like males and this brings us to a doubt about the activity of the bourgeois Bari. But analyzing the cases we did not have any sick women even though they are on the same dose of X chromosome as men.

From this it is understood that the "inactive" chromosome Heterocyclic or Barr body only in morphological view differs from other sexous chromosome having the form $(\mathrm{X})$, if it is functional and with its own genetic radiation contributes to enzymatic processes and hence inhibits enzyme pathogens in female sex. This is confirmed by the fact that if females find hemophilic occur in both sex chromosomes $\mathrm{X}$ women will be sick. Therefore, there is no dilemma that heterochromatin or body barr is partially active but only in shape varies and captures the appearance of a nucleus in the nucleus.

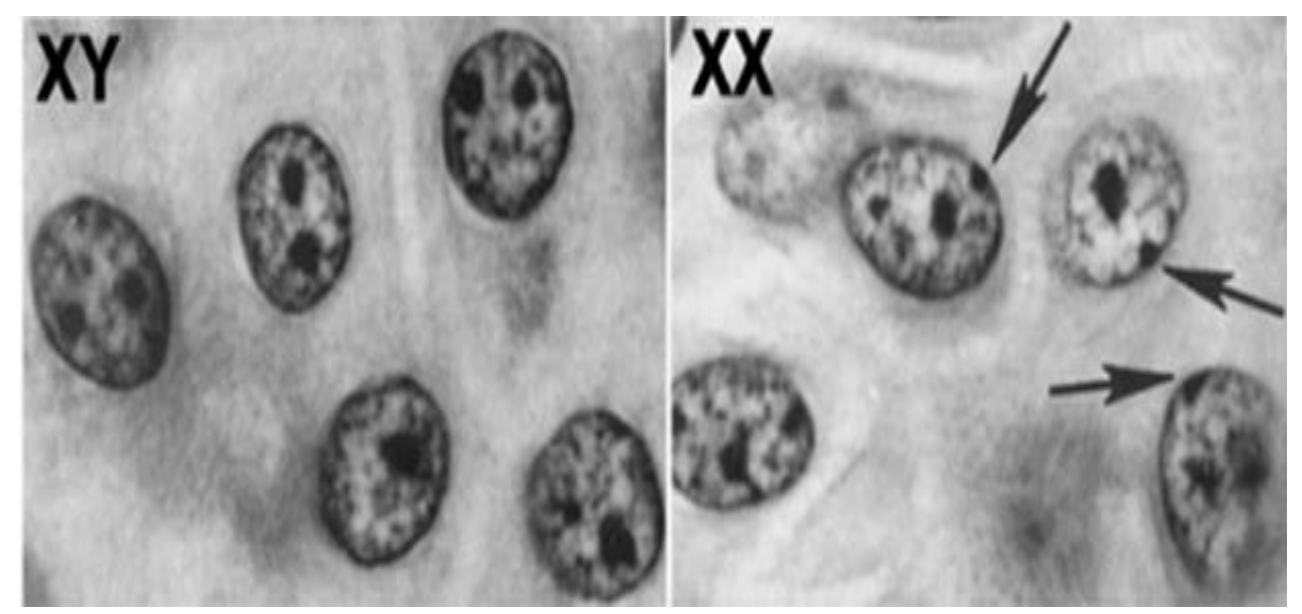

Fig.1. Heterochromatina

In this family we had a case of hemophiliaus where the individual number III 8 of the female gender is the carrier of hemophilia, but not sick. So it is not possible to say that the mutation of this disease has occurred in the body of Bari and not in the sex X chromosome. Also the same case is in the IV10 generation where we have sick hemophilic (dead) son and two sisters in generation IV14 and IV15 as haemophilic carriers, the subconscious that finds mutation is found in the body of Bari or in the X chromosome. From female IV14 we have a boy with hemophilia 
V9 and from her sister IV15 sibarthe to hemophilia we have two brothers V11 immortal while the V12 is weed.

This is confirmed by the fact that female III8 in her marriage has a hemophilic boy IV10 and a healthy IV12 and two girls carrying haemophilia (IV14 and IV15).

a)

Genealogical analysis of hemophiliac disease
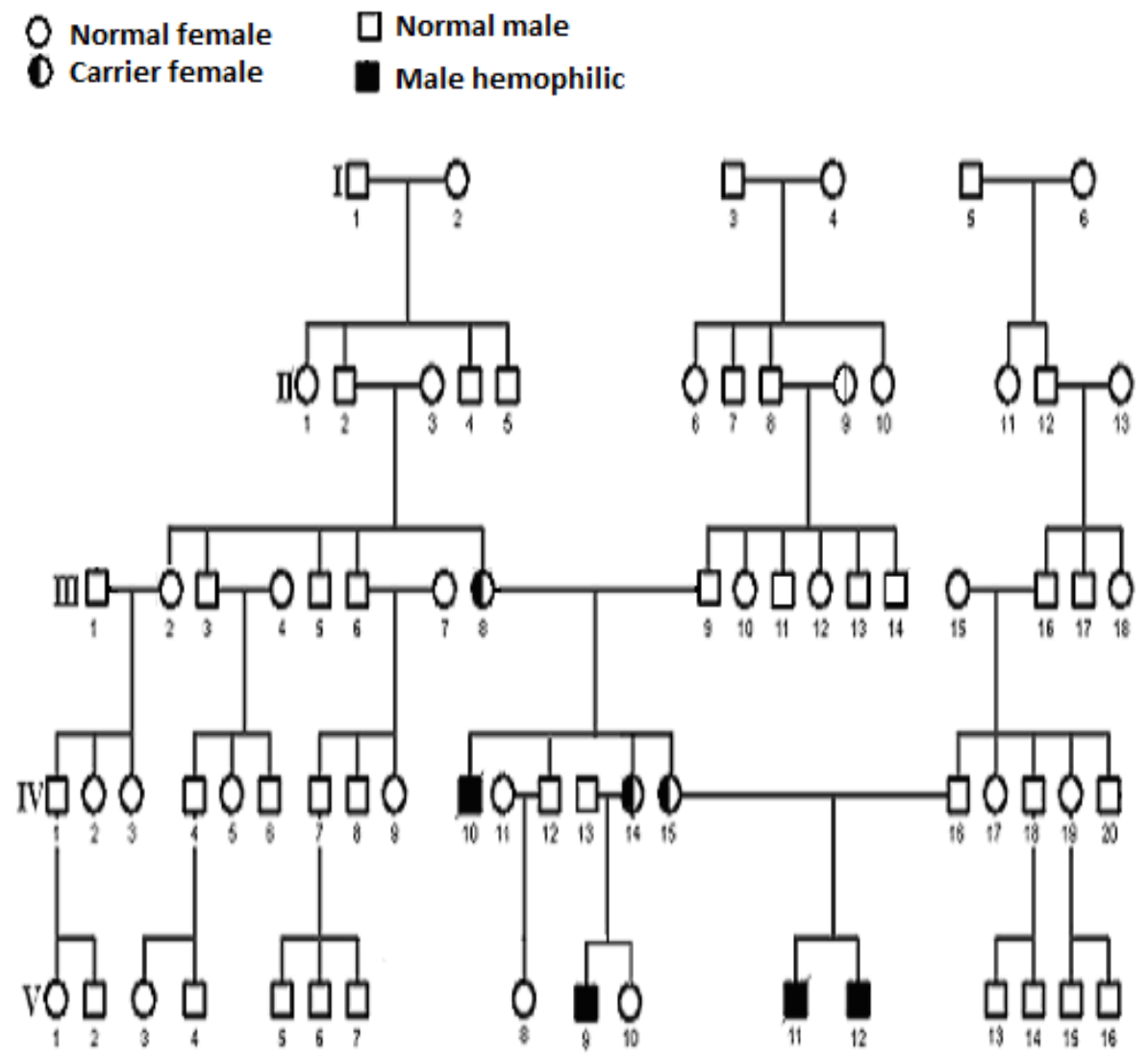

Fig.2. Genealogy of hemophilia

\section{b) Analysis of laboratory results}

From laboratory analysis at the Nis Health Institute, two brothers and their cousins from their mothers have hemophilia A-type A blood-negative A-Rh. Apparently factor VIII in three cases has a deficiency in the brothers: $1.7 \%$ and the other $1.5 \%$ of the action, while the cousin $2 \%$. The results of three cases with hemophilia are presented in Table 1.

In the three cases it is about mutation of intron 22 in Xq28 region of chromosome X.

Table 1. Laboratory, biochemical and genetic results of haemophilists 


\begin{tabular}{|l|l|l|l|}
\hline $\begin{array}{l}\text { Three cases with } \\
\text { hemophilia } \\
\text { Biochemical and } \\
\text { genetic results }\end{array}$ & $\begin{array}{l}\text { The first } \\
\text { individual (first } \\
\text { brother) }\end{array}$ & $\begin{array}{l}\text { The second } \\
\text { person (second } \\
\text { brother) }\end{array}$ & $\begin{array}{l}\text { The third person, } \\
\text { the cousin of the } \\
\text { two brothers }\end{array}$ \\
\hline $\begin{array}{l}\text { Type of } \\
\text { hemophilia }\end{array}$ & $\begin{array}{l}\text { Hemophilia } \\
\text { type A }\end{array}$ & $\begin{array}{l}\text { Hemophilia type } \\
\text { A }\end{array}$ & $\begin{array}{l}\text { Hemophilia type } \\
\text { A }\end{array}$ \\
\hline Blood group & A, Rh negative & A,Rh negative & A,Rh negative \\
\hline Factor VIII level & $\begin{array}{l}1.7 \% \\
\text { Preferably 50- } \\
150 \%)\end{array}$ & $\begin{array}{l}1.5 \% \\
\text { Preferably } \\
150 \%)\end{array}$ & $\begin{array}{l}2 \% \text { ( Preferably } \\
50-150 \%)\end{array}$ \\
\hline Factor I level & $338,5 \%$ & $338 \%$ & $339 \%$ \\
\hline Factor IX level & $91,5 \%$ & $91 \%$ & $91 \%$ \\
\hline Factor XI level & $82.8 \%$ & $83 \%$ & $83 \%$ \\
\hline Fibrinogen & $4.01 \%$ & $4 \%$ & $4 \%$ \\
\hline Genotype & ccddee & ccddee & ccddee \\
\hline Intron 22 & Region Xq28 & Region Xq28 & Region Xq28 \\
\hline
\end{tabular}

Therefore, we can conclude that the inheritance of these factors is done with a high and independent genetic stability without any factor VIII interference resulting from mutation in intron 22 in Xq28 region of chromosome X. So we conclude that the other factors analyzed in this study have not changed from the mutation of the gene that induces hemophilia.

In these cases, we can say that the mutation of the hemophilic gene does not represent any correlation with factors I, IX, XI and fibrinogen, while there are signs with the blood group and the rhesus factor, therefore a genealogical and molecular research should be performed.

\section{Conclusions}

1. By analyzing the genealogy tree or the genetic tree it is clearly seen that only masculine is affected by hemophilia, while the female gender is a carrier, but heterozygous is not ill. By this we certify that the so-called inactive chromosome Heterocchromatin or the body of Bari is not completely inactive, but in these cases it is self-evident that it is functional forming blood clotting enzymes.

2. Regardless of who and what happens X inactivation, however, activity in the formation of the encoding enzyme is active. So it just seems to be ineffective but in reality the genius works when it comes to the disease. The hemophilic source is female with a number 8 strain of generation III that has undergone intron mutation 22 in Xq28 region of chromosome $\mathrm{X}$.

3. Analyzing genealogy of families, we can conclude that it comes to a new mutation for hemophilia.

4. Factor VIII level of action in three cases is very low: $1.7 \% ; 1.5 \%$ and $2 \%$ compared to the preferred value, $(50-150 \%)$.

5. Also Bari's body may be partially inactive, but it is completely safe.

6. In the early stage, at the end of the first week of pregnancy, before implantation of the embryo in the uterus occurs the morphological change, the inactivation of the $\mathrm{X}$ chromosome originating from the sperm, and this proves that their father was not hemophilic and the body of Bari is non-carrier of hemophilia in these three cases, but the mother was carriers but not sick. 7. As a solution to this problem, evolution has determined that women always modify an $\mathrm{X}$ chromosome, because the space in the nucleus is not inactive completely. And this is accomplished precisely by DNA methylation in histone on a X chromosome of the father who is subject to the egg cell's egg-like factor because it does not find fit in another cell that has a completely different opposite to where it came from. And due to the action of the cytoplasm 
and cellular enzymes of the chromosome $\mathrm{X}$ egg cell from the father undergoes a condensation in the body of Bari.

\section{REFERENCE}

1. Dumanović, J, Marinković, D, Denić, M: Genetički rečnik, Beograd, 1985

2. Elgin, S.C. (1996). "Heterochromatin and gene regulation in Drosophila". Current Opinion in Genetics \& Development. 6 (2): 193-202. doi:10.1016/S0959-437X(96)80050-5. ISSN 0959-437X.

3. Fisher, Amanda G.; Matthias Merkenschlager (April 2002). "Gene silencing, cell fate and nuclear organisation". Current Opinion in Genetics \& Development. 12 (2): 193-7. doi:10.1016/S0959-437X(02)00286-1. ISSN 0959-437X. PMID 11893493.

4. Rosenfeld, Jeffrey A; Wang, Zhibin; Schones, Dustin; Zhao, Keji; Desalle, Rob; Zhang, Michael $Q$ (31 March 2009). "Determination of enriched histone modifications in nongenic portions of the human genome". BMC Genomics. 10 (1): 143. doi:10.1186/1471-216410-143. PMC 26675392. PMID 19335899.

5. Roudier, François; et al. (2011). "Integrative epigenomic mapping defines four main chromatin states in Arabidopsis". The EMBO Journal. 30 (10): 1928-1938.

doi:10.1038/emboj.2011.103. PMC 3098477\%. PMID 21487388.

6. Tucić, N, Matić, Gordana: O genima i ljudima, Centar za primenjenu psihologiju, Beograd, 2002.

7. Vavasseur; et al. (2008). "Heterochromatin Assembly and Transcriptional Gene Silencing under the Control of Nuclear RNAi: Lessons from Fission Yeast". RNA and the Regulation of Gene Expression: A Hidden Layer of Complexity. Caister Academic Press. ISBN 978-1-904455-25-7. 